3 Research Square

\title{
Trichoderma asperellum as a promising mycofungicide for managing the dieback disease of tea Camellia sinensis (L.) Kuntze
}

kishor kumhar ( $\square$ kishorkumarc786@gmail.com )

Chaudhary Charan Singh Haryana Agricultural University

Azariah Babu

Tea Research Association

John Peter Arulmarianathan

Varsha Bioscience India Private Limited

Bhabesh Deka

Tea Research Association

Mitali Bordoloi

Tea Research Association

Hirakjyoti Rajbongshi

Tea Research Association

Pritam Dey

Tea Research Association

Research article

Keywords: Trichoderma asperellum $2 \%$ AS, tea, dieback, yield, beneficial insects, phytotoxicity

Posted Date: January 21st, 2021

DOI: https://doi.org/10.21203/rs.3.rs-58156/v3

License: @) (i) This work is licensed under a Creative Commons Attribution 4.0 International License. Read Full License 


\section{Abstract}

Background: The dieback disease of tea caused by Fusarium solani is one of the major constraints in determining its production and quality. Genus Trichoderma is a promising biocontrol agent to control the dieback without any residual effect and is the most suitable option for integrated disease management approach. A few local Trichoderma spp were isolated from tea rhizosphere of the Dooars zone and preliminary identified. Based on dual culture bioassay, the most efficient isolate got re-identified from well reputed national institutes and its liquid formulation ( $2 \%$ Aqueous Suspension) was prepared. Different concentrations of this formulation, T. harzianum and Hexaconazole were evaluated for the control of dieback disease and other parameters for two seasons in three zones under field conditions.

Results: The fungal antagonist (KBN-29) was identified as T. asperellum based on characteristics such as regular mycelial branching, typically paired conidiophores with straight phialides and globose to sub-globose shaped conidia. It had the maximum control of dieback pathogen in lab experiment. Spray of T. asperellum formulation at 1200 and $1000 \mathrm{ml} /$ ha concentration conferred comparatively better disease control and enhanced the yield of green tea leaves. The formulation was safe to non-target beneficial insects in all three zones without any phytotoxicity to tea leaves at 4,8 , and $16 \mathrm{ml} / \mathrm{L}$ concentrations.

\section{Conclusions}

The present study confirms that T. asperellum $2 \%$ AS formulation was significantly superior in managing the dieback disease of tea plantations in Darjeeling, Dooars, and Assam zones at concentration of 1200 followed by $1000 \mathrm{ml} /$ ha during both seasons. The maximum made tea yield was achieved in plots treated with $T$. asperellum at 1200 followed $1000 \mathrm{ml} / \mathrm{ha}$. This formulation was safe to beneficial insects viz., $C$. carnea, $O$. javanus, and $S$. gilvifrons, furthermore it was not phytotoxic to tea leaves at 4 to $16 \mathrm{ml} / \mathrm{L}$ concentrations.

\section{Background}

Tea (Camellia sp) is one of the most popular non-alcoholic beverages in the world next to the water. In India, it is grown as a perennial monoculture plantation crop which may be yielding even up to 50-150 years. The young shoots comprising of two or three leaves and a bud is primarily used as the base material for manufacturing tea. Based on the fermentation process there are three varieties of tea like non-fermented (green tea), semifermented (oolong tea), and fermented (black tea) are consumed by people according to the preference and their taste. In India, tea is cultivated in about 6.36 lakh hectares with a production of about 1,338 million kg made teas [1]. Among North-eastern Indian states, Assam is well known for producing premium CTC tea and the Darjeeling area of West Bengal is famous for orthodox tea, best known as Champagne of teas and known for its aroma and flavor.

Attack of several fungal diseases such as root rots, leaf spots, and stem canker play a key role in determining the bountiful tea production [2]. The dieback disease caused by Fusarium solani is considered as one of the most economically important foliar diseases of this crop responsible for huge crop losses because it directly infects the young shootswhich are the basic input of manufactured teas [3]. The disease incidence has been increasing day by day owing to climate change and many others factors [4]. Dieback infection starts from the leaf petiole and it progress in both directions and ultimately resulted in to disease symptoms in form of dead and chlorotic shoots which are useless for manufacturing of teas. An effective management of this disease can be achieved through chemical fungicides; however it is restricted in organic tea gardens, because their excessive use may lead to deterioration of soil health, pollution of groundwater, resistance development in phytopathogens, destruction of several beneficial organisms, and eventually cause human health problems [5] [6] [7].

Under such circumstances, the application of biopesticides could be an appropriate alternative approach to take care of this disease in tea plantations. The biopesticides are considered important as they are safer to human beings, environment, beneficial microbes besides its quickly decomposing nature [8] [9]. Among biopesticides, the fungus belongs to the genus Trichoderma is the best candidate in managing various diseases of different crops. Among the several species of Trichoderma, T. harzianum, H. lixii, T. atroviride, H. atroviridis, T. asperellum, and T. virens are reported as potential biocontrol agents against phytopathogens [10] [11] and the potency of genus Trichoderma has already been established for the control of numerous phytopathogenic fungal genera of agricultural importance [12]. It parasitizes the phytopathogenic fungi through the detection of the host, attachment to host followed by its coiling, releasing of secondary metabolites such as antibiotics, and production of cell wall degrading enzymes [13]. Trichoderma produces certain compounds like isonitrile, diketopiperazines, sesquiterpenes, polyketides, alkylpyrones, and peptaibols [14]. Looking at the usefulness of genus Trichoderma as a potential biological control agent (BCA) in managing the fungal diseases successfully, the present study was aimed at the isolation and identification of indigenous Trichoderma spp, selection of most promising isolate and establishing its proper identity through morphological characters as well as DNA fingerprinting, getting its accession number followed by development and field bioefficacy of liquid formulation against dieback disease, its effect on leaf yield, beneficial insects and phytotoxicity on tea plants for two successive years under three geographical locations i.e. Darjeeling, Dooars and Assam. The ultimate aim of this study was to develop promising Trichoderma strain and make it available at large scale for the benefit of the tea industry as suitable control measure of dieback disease of tea plantation.

\section{Results}


A few local fungal antagonists were isolated from the tea rhizosphere of Dooars zone, District Jalpaiguri, West Bengal, India. Based on the cultural and morphological characters as well as microscopic observations, the isolates were tentatively identified as Trichoderma spp.

\section{Isolation of $F$. solani}

The phytopathogenic fungus could produce light pinkish colored colony on PDA. Microscopic visualization revealed both micro as well as macroconidia. The macroconidia were sickle shaped with 2-3 transverse septa.

\section{Selection of promising Trichoderma sp}

Among the evaluated Trichoderma isolates, T. asperellum (KBN-29) showed the highest potency in controlling the $F$. solani in dual culture when compared with untreated control plate wherein it could attain $64.3 \mathrm{~mm}$ diameter of mycelial growth after one week. Owing to its fast growth and abundant sporulation, it competed strongly with the pathogenic fungus for space as well as nutrients and made unfavorable conditions for growth and conidiation of counter fungus (fig. 1 and 2).

Based on the dual culture assay performance, the antagonist was further got identified from ITCC, Division of Mycology and Plant Pathology, IARI, Pusa, New Delhi - 110012 as T. asperellum with an accession number : ITCC-7764. Further, National Bureau of Agriculturally Important Microorganisms, Indian Council of Agricultural Research, Kushmaur, Mau, Uttar Pradesh, India, re-confirmed the same identity and assigned an accession number as NAIMCC-SF-0041 (Fig. 3).

The liquid formulation from $T$. asperellum was prepared in the form of $2 \%$ Aqueous Suspension (AS) using a liquid fermentation technique to carry out different studies.

\section{Multilocation field Bio-efficacy of $T$. asperellum $2 \%$ AS on dieback disease during the season I and II}

In the Darjeeling zone, the pre-spray dieback infection (Fig. 4A) ranged from 15.78-18.11 shoots. The first spray could reduce dieback infection in all the treated plots as compared to untreated ones. Among the treatments, T. asperellum $2 \%$ AS at $1000 \mathrm{ml}$ and $1200 \mathrm{ml} /$ ha concentrations were found more effective in controlling the disease with two rounds of spraying (Fig. 4B and C) which gave superior control of disease as compared to its lower concentrations and market sample (T. harzianum) $2500 \mathrm{~g} /$ ha. However, hexaconazole $5 \%$ EC exhibited the maximum disease reduction in both seasons (Table 1).

In Dooars and Assam zones, pre-spray infection ranged from 19.89 to 22.67 and 20.67 to 23.33 , respectively in the first season. All concentrations of T. asperellum performed better over untreated control and T. harzianum; however, 1000 and 1200 ml concentrations were found more effective. In the second season a similar trend of disease control was recorded in both zones (Table 2 and 3 ).

\section{Effect of T. asperellum formulation on the yield of green leaves}

The average green leaf yield of first six rounds harvesting at the weekly interval in T. asperellum sprayed plots with $1000 \mathrm{ml}$ and $1200 \mathrm{ml} / \mathrm{ha}$ was found significantly superior over the Hexaconazole 5\% EC and T. harzianum. T. asperellum 2\% AS at $1000 \mathrm{ml}$ and $1200 \mathrm{ml} / \mathrm{ha}$ showed an increased average made tea yield of 422 and $425 \mathrm{~kg} / \mathrm{ha}$, respectively during the first season and 395 and $399 \mathrm{~kg} / \mathrm{ha}$, respectively during the second season as compared to untreated control where it was 377 and $354 \mathrm{~kg} / \mathrm{ha}$ in the first and second season, in Darjeeling zone. However, in Dooars zone, the yield of made tea was 1694 and $1703 \mathrm{Kg}$ at concentration of $1000 \mathrm{ml}$ and $1200 \mathrm{ml} / \mathrm{ha}$ as compared to $1519 \mathrm{~kg}$ in control in the first year whereas it was 1724 and $1729 \mathrm{~kg}$ at both higher concentrations as compared to control (1543) in the second season. The same yield trend was observed in the Assam zone, where yield in the first year was higher (2315 and $2324 \mathrm{~kg}$ ) at both higher concentrations as compared to control $(2071 \mathrm{~kg})$. In the second season, it was 2216 and $2229 \mathrm{~kg}$ at higher doses against $1983 \mathrm{~kg}$ in control during the second year (Table 4 ). Both higher concentrations of developed formulation had increased the green leaf yield over control during both seasons in Darjeeling (11.93 -12.73\%), Dooars (11.73 - 12.11\%) and Assam (11.78 - 12.40\%).

\section{Effect of the formulation on beneficial insects}

The population status of important beneficial insects viz., C. carnea, 0 . javanus, and S. gilvifrons was recorded at 0 day, $7^{\text {th }}$ day of the first spray, and $7^{\text {th }}, 14^{\text {th }}$ and $21^{\text {st }}$ day of the second spray during season 1 and 2 (Fig. 5-7). The experimental results indicated that the local formulation did not show any adverse effect on the population-status of these beneficial insects.

\section{Testing for phytotoxicityand tainting}

Tea leaves on the bushes were observed for phytotoxic effects after the spray of $T$. asperellum $2 \%$ AS. The results indicated that there were no phytotoxic effects in form of wilting of leaves, vein clearing, necrosis, epinasty, and hyponasty on the tea leaves at the 4 to 16 ml per litre concentrations used in the study. There was no tainting effect on tea leaves of the evaluated formulation. 


\section{Discussion}

In the present study, different concentrations of $T$. asperellum (2\% AS) liquid formulation successfully controlled the dieback disease at all locations, and hence, it could be an alternate approach of disease management under organic crop production system of Darjeeling and other areas. Foliar spray of Trichoderma formulation resulted in an increased number of shoots and their length [15]. It was found that Trichoderma WP formulation controlled the dieback disease of tea to a great extent when sprayed at 2.5 and $5.0 \mathrm{~g} /$ liter concentration and performed better than the commercial formulation of the antagonist. Light pruned (LP) and deep skipped (DS) tea bushes showed enhanced vegetative growth as compared to control [16]. Foliar spray of $T$. harzianum and $T$. viride on wheat crop managed head blight disease caused by Fusarium graminearum under greenhouse conditions better than control [17]. Trichoderma spp was found to be promising under field conditions for the management of blister blight of tea in North East India. The efficacy of $T$. atroviride strains has proven for the protection of pruning wounds in the grapevine [18]. $T$. asperellum was successful in managing a broad array of fungal phytopathogens [19] [20] such as F. oxysporum and Curvularia aeria [21] [22]

Our study showed the increased production of healthy green tea shoots due to the application of $T$. asperellum liquid formulation as compared to chemical fungicide, T. harzianum, and control. Hence there are chances to get bountiful production of tea crop by applying it as a foliar spray besides controlling the disease. T. asperellum showed synergistic activity with Bacillus amyloliquefaciens and combined application of both microbes significantly enhanced the growth of wheat as well as protected the crop against plant pathogens [23].

The liquid formulation of the local antagonist did not adversely affect the beneficial insects of the tea ecosystem and confirmed the earlier findings that the biopesticides are less toxic, decomposes quickly, free from pollution, and residue problems. They generally affect the targeted and closely related organisms in the same environment [8][9]. The spray of fish emulsion increased the yield of tomatoes and peppers with no observable phytotoxic effect on crop foliage under the field conditions [24]. The developed liquid formulation was found to be non-phytotoxic without showing any kind of toxicity symptoms on tea leaves.

\section{Conclusions}

It is concluded that $T$. asperellum $2 \%$ AS formulation effectively managed the dieback disease of tea plantations in Darjeeling, Dooars, and Assam zones at concentration of 1200 followed by $1000 \mathrm{ml} /$ ha during both seasons. The maximum made tea yield could achieve when T. asperellum sprayed at 1200 was followed $1000 \mathrm{ml} / \mathrm{ha}$. The antagonist's formulation found safer to beneficial insects viz., $C$. carnea, 0 . javanus, and $S$. gilvifrons. Moreover the formulation did not reveal phytotoxicity on tea leaves at 4 to $16 \mathrm{ml} / \mathrm{L}$ concentrations.

\section{Methods}

\section{Isolation and identification of Trichoderma sp}

Isolation of the antagonist was carried out following standard technique with slight modification [25]. Soil samples at a depth of 12 inches were collected from tea rhizosphere in sterilized polyethylene bags, brought to mycology laboratory, stored in the refrigerator at $4 \pm 1^{0} \mathrm{C}$. For isolation of antagonistic fungi, soil samples were homogenized processed following multiple serial dilution plate technique (MSDP). From $6^{\text {th }}$ and $8^{\text {th }}$ dilutions, $0.5 \mathrm{~mL}$ was drawn and uniformly distributed in solidified Trichoderma specific medium (HiMedia) plates in triplicates. Plates were then properly sealed with parafilm and incubated at $28 \pm 2{ }^{\circ} \mathrm{C}$ for $72-96$ hours. Appeared fungal colonies were observed and antagonist's colonies were identified based on its mycelia color and fast-growing character. Such colonies were transferred into another potato dextrose agar (PDA) plates for getting pure culture and re-incubated at $28 \pm 2{ }^{\circ} \mathrm{C}$ for 96 hours in the BOD incubator.

\section{Isolation of Fusarium solani}

Tea shoots infected with dieback disease, were collected in sterilized polyethyle bags and stored in the refrigerator till further process. The infected shoots were washed thoroughly in running tap water followed by surface sterilization with sodium hypochloride (1.0\%) for 5 minutes. Then the shoots were ringed with distilled sterilized water twice and dried in blotter paper. Small pieces were cut and transferred in to solidified PDA plates; plates were sealed properly with parafilm and incubated at $28 \pm 2{ }^{\circ} \mathrm{C}$ for $5-7$ days in the BOD incubator. The appeared light pinkish colored fungal colonies were transferred in to PDA slants after one week to get pure culture of pathogenic fungus. It was visualized microscopically for the identification based on the anatomy of micro and macroconidia.

\section{Selection of potent isolate}

To screen the most potent Trichoderma isolate, seven isolates were studied through dual culture bioassay [26]. The mycelia bits (5 mm diameter) of $F$. solani and antagonists were inoculated in to same potato dextrose agar plate of $90 \mathrm{~mm}$ diameter followed by proper sealing and incubation at $28 \pm 2{ }^{\circ} \mathrm{C}$ for one week. Complete randomized design (CRD) was adopted for in vitro study. Three replications of each treatment (isolate) were maintained. Colony diameter was observed and per cent growth inhibition was calculated using the formula (Per cent growth inhibition = colony diameter in control - colony diameter in treatment / colony diameter in control x 100). 
For the re-confirmation and having accession number, the most promising isolate was sent to Indian Type Culture Collection, Division of Mycology and Plant Pathology, Indian Agricultural Research Institute, Pusa, New Delhi, and ICAR National Bureau of Agriculturally Important Microorganisms, Indian Council of Agricultural Research, Kushmaur, Mau, Uttar Pradesh, India.

\section{Development of formulation: T. asperellum $2 \%$ Aqueous Suspension}

The liquid formulation of $T$. asperellum was manufactured using liquid-state fermentation techniques by M/s Varsha Bioscience and Technology India Pvt Ltd, Hyderabad - 500059, Telangana, India using the slightly modified method [27]. The mother culture of the antagonist was sub-cultured on to plates containing Trichoderma Specific Media (TSM) followed by incubation at $28 \pm 2{ }^{\circ} \mathrm{C}$ for 5 days.

Then 10 liters of seed inocula was prepared by inoculating $120 \mathrm{hr}$ old mother culture into $1000 \mathrm{ml}$ conical flask filled with $250 \mathrm{ml}$ autoclaved potato dextrose agar and incubated in an orbital shaker at $28 \pm 2^{\circ} \mathrm{C}$ and $180 \mathrm{rpm}$ for seven days. From seed inocula, submerged large scale fermentation was done to scale up its quantity using another autoclaved medium containing $30 \mathrm{~g}$ sugarcane molasses and $5 \mathrm{~g}$ yeast extract per liter of water. One week old seed inocula (10\%) was inoculated in the fermenter incubated for 7 days and the cultural biomass was separated by centrifuging the culture broth through the on-line centrifugation system and both the conidia, as well as mycelia were collected. Active ingredient $\left(2 \times 10^{8} \mathrm{CFU} / \mathrm{ml}\right)$ was determined by the MSDP technique in final formulation by adding required distilled sterilized water.

\section{Multilocation field Bio-efficacy of T. asperellum $2 \%$ AS on dieback disease during the season I and II}

The T. asperellum 2\% AS formulation was tested under field conditions at Darjeeling, Dooars, and Assam zones against dieback disease caused by F. solani from 2016 to 2018. The plot size was kept $84 \mathrm{~m}^{2}$ for each treatment with 100 bushes. Experiments were laid out in randomized block design (RBD) with seven treatments in three replications. Common tea cultivars/clones of particular zone namely AV-2, TV-25 and TV-1 were chosen for the study for Darjeeling, Dooars and Assam zone, repectively.

The plots having dieback disease incidence above 5\% ETL were selected for field bio-efficacy study. The disease incidence was recorded by placing a 1 x 1-foot quadrate at 3 randomly selected spots per treatment then healthy and infected tea shoots were plucked. Then the first spray with hand operated knapsack sprayer fitted with NMD 450 nozzle was done immediately after the plucking (0-day). Observations on disease incidence were recorded on the $7^{\text {th }}$ day of the first spray using the same quadrate. Subsequently, both healthy and infected shoots were plucked on the same day and weight of the fresh healthy shoots was recorded. The second spray was given on the $7^{\text {th }}$ day after the $1^{\text {st }}$ spray and disease incidence was recorded on the $7^{\text {th }}, 14^{\text {th, }}$ and $21^{\text {st }}$ days of the second spray.

\section{Effect of $T$. asperellum formulation on the yield of green leaves}

Green leaf yield (kg/plot) was recorded from the first six rounds of plucking and at every plucking round it was converted into made tea per hectare using the formula [28].

Made tea $\mathrm{Kg}$ per hectare $(\mathrm{KMTH})=$ Green leaf yield $(\mathrm{Kg}) \times$ no. of bushes/ha $\times$ Conversion Factor $(0.225)$

\section{Effect of the formulation on beneficial insects}

The population of beneficial insect viz., Chrysoperla carnea, Oxyopes javanus, and Stethorus gilvifrons was recorded on 0 days (pre-spray), $7^{\text {th }}$ day of $1^{\text {st }}$ spray and $7^{\text {th }}, 14^{\text {th }}$ and $21^{\text {st }}$ day of $2^{\text {nd }}$ spray (post-spray). Visual observations were made from 30 randomly selected tea bushes per treatment to assess the population of $C$. carnea nymphs and $O$. javanus adults. Thirty leaves were collected at random per treatment and observed under a binocular microscope for assessing the population of S. gilvifrons.

\section{Testing for phytotoxicityand tainting}

The developed formulation was sprayed at concentration of 4,8 , and $16 \mathrm{ml}$ per liter water to assess its phytotoxic effects on tea leaves. Three replications were maintained in 84 square meters area of the experimental plot. Observations were recorded on $0,3,7$, and $14^{\text {th }}$ day of spray for the appearance of leaf yellowing, stunting, necrosis, epinasty, and hyponasty type symptoms and the injury level (toxic level) was rated using the following phytotoxicity rating scale (PRS). Tainting effect was visually observed in form of changing of colour of leaves from normal green to abnormal green coloured. 
Crop response / Crop injury (\%) Rating

\begin{tabular}{|c|c|}
\hline 0.0 & 0 \\
\hline $1-10$ & 1 \\
\hline $11-20$ & 2 \\
\hline $21-30$ & 3 \\
\hline $31-40$ & 4 \\
\hline $41-50$ & 5 \\
\hline $51-60$ & 6 \\
\hline $61-70$ & 7 \\
\hline $71-80$ & 8 \\
\hline $81-90$ & 9 \\
\hline $91-100$ & 10 \\
\hline
\end{tabular}

The percent phytotoxicity index (PPI) was computed using the following formula,

Sum of all numerical ratings

$\mathrm{PPI}=$ $-x 100$

Number of tea plant observed x Maximum phytotoxicity rating

\section{Statistical analysis}

The collected data were statistically analyzed to find out the critical difference among treatment at a $5 \%$ level of significance $(p=0.05)$ through the online statistical package "OPSTAT" of Chaudhary Charan Singh Haryana Agricultural University, Hisar (www.hau.ac.in).

\section{Abbreviations}

2\% AS: 2\% Aqueous Suspension; Cc: Chrysoperla carnea; Oj: Oxyopes javanus; Sg: Stethorus gilvifrons; ITCC: Indian Type Culture Collection; IARI: Indian Agricultural Research Institute; LP: Light pruned; DS: Deep skipped; Ta: T. asperellum; Th: T. harzianum; Hexa: Hexaconazole DAS: days after spray; TRA: Tea Research Association; NBAIM: National Bureau of Agriculturally Important Microorganisms; BCA: Biological Control Agent; PDA: Potato dextrose agar.

\section{Declarations}

\section{Ethics approval and consent to participate}

Not applicable

\section{Consent for publication}

Not applicable

\section{Availability of data and materials}

The datasets generated and analyzed during the current study are not publicly available due to privacy reasons but are available from the corresponding author on reasonable request.

\section{Competing interests}

The authors declare that they do not have competing interests.

\section{Funding}

At present we do not have any financial support from any funding agency for this research work to get it published. However, the waivers (BMC Plant Biology Journal) considered it for the review process without article processing charges.

\section{Authors' contributions}


KCK: Isolated, identified the T. asperellum, developed SOP for field trials, tabulated results, and written the manuscript. AB: Decided the experimental locations, analyzed the data, and provided overall guidance. JPA: Developed protocol for product formulation of antagonist and made it available for field trials. BD: Shaped the manuscript as per the Journal's format. MB: Conducted field trials in selected zones. HR and PD: Collected data of all experiments. All authors read and approved the final manuscript.

\section{Acknowledgments}

The authors are highly thankful to the Biotechnology Industry Research Assistance Council (BIRAC) for sanctioning the research project under the CRS scheme to develop local strains of antagonist and entomopathogenic fungi. We are thankful to Dr. Prameela Devi and Dr. Deeba Kamil, Division of Mycology and Plant Pathology, Indian Agricultural Research Institute (IARI) Pusa, New Delhi, for their help in the identification of Trichoderma strain and assigning an accession number as ITCC-7764. The DNA fingerprinting done through outsourcing from ICAR-NBAIM, Kushmaur, Mau, Uttar Pradesh- 275103, India, is also acknowledged.

\section{References}

1. Anonymous. Tea Board India: http://www.teaboard.gov.in/pdf/Area_1_pdf2863.pdf /Production_Region_wise_pdf2736.pdf. Accessed 4 August 2020. 2018.

2. Kumhar KC, Babu A. Economically Important Diseases of Tea (Camellia sp.) and Their Management. In: Diseases of Fruits and Vegetable Crops. 2020. p. 435-59.

3. Lehmann-Danzinger H. Diseases and Pests of Tea: Overview and Possibilities of Integrated Pest and Disease Management. Journal of Agriculture in the Tropics and Subtropics. 2000.

4. Sanjay R, Ponmurugan P, Baby Ul. Evaluation of fungicides and biocontrol agents against grey blight disease of tea in the field. Crop Prot. 2008;27:689-94.

5. Sarwar M. The Killer Chemicals as Controller of Agriculture Insect Pests: The Conventional Insecticides. Int J Chem Biomol Sci. 2015;1:141-7.

6. García-García CR, Parrón T, Requena M, Alarcón R, Tsatsakis AM, Hernández AF. Occupational pesticide exposure and adverse health effects at the clinical, hematological and biochemical level. Life Sci. 2016;145:274-83.

7. Shammi M, Sultana A, Hasan N, Mostafizur Rahman M, Saiful Islam M, Bodrud-Doza M, et al. Pesticide exposures towards health and environmental hazard in Bangladesh: A case study on farmers' perception. J Saudi Soc Agric Sci. 2020;19:161-73.

8. Leahy J, Mendelsohn M, Kough J, Jones R, Berckes N. Biopesticide oversight and registration at the U.S. Environmental Protection Agency. In: ACS Symposium Series. 2014. p. 3-18.

9. Villaverde JJ, Sevilla-Morán B, Sandín-España P, López-Goti C, Alonso-Prados JL. Biopesticides in the framework of the European Pesticide Regulation (EC) No. 1107/2009. Pest Manag Sci. 2014;70:2-5.

10. Jeger MJ, Jeffries P, Elad Y, Xu XM. A generic theoretical model for biological control of foliar plant diseases. J Theor Biol. 2009;256:201-14.

11. Hjeljord L, Tronsmo A, Harman GE, Kubicek C. Trichoderma and Gliocladium in biological control: an overview. 1998.

12. Contreras-Cornejo HA, Macías-Rodríguez L, Del-Val E, Larsen J. Ecological functions of Trichoderma spp. and their secondary metabolites in the rhizosphere: interactions with plants. FEMS microbiology ecology. 2016;92:fiw036.

13. Zeilinger S, Gruber S, Bansal R, Mukherjee PK. Secondary metabolism in Trichoderma - Chemistry meets genomics. Fungal Biology Reviews. 2016;30:74-90.

14. Patil AS, Patil SR, Paikrao HM. Trichoderma secondary metabolites: Their biochemistry and possible role in disease management. In: Microbial-Mediated Induced Systemic Resistance in Plants. 2016. p. 103-24.

15. Kumhar KC, Babu A. In vitro study on bio-efficacy, fungicide tolerance and shelf life of local isolate of Trichoderma viride. Two a Bud. 2015;62:17-20.

16. Kumhar KC, Babu A, Arulmarianathan JP, Deka B, Bordoloi M, Rajbongshi H, et al. Role of beneficial fungi in managing diseases and insect pests of tea plantation. Egypt J Biol Pest Control. 2020;30.

17. Panwar V, Aggarwal A, Singh G, Saharan MS, Verma A, Sharma I, et al. Efficacy of foliar spray of Trichoderma isolates against Fusarium graminearum causing head blight of wheat. J Wheat Res. 2014.

18. Mondello V, Larignon P, Armengol J, Kortekamp A, Vaczy K, Prezman F, et al. Management of grapevine trunk diseases: Knowledge transfer, current strategies and innovative strategies adopted in Europe. Phytopathologia Mediterranea. 2018;57:369-83.

19. Marcello CM, Steindorff AS, da Silva SP, Silva R do N, Mendes Bataus LA, Ulhoa CJ. Expression analysis of the exo- $\beta-1,3-g l u c a n a s e$ from the mycoparasitic fungus Trichoderma asperellum. Microbiol Res. 2010;165:75-81.

20. Wu Q, Zhang L, Xia H, Yu C, Dou K, Li Y, et al. Omics for understanding synergistic action of validamycin A and Trichoderma asperellum GDFS1009 against maize sheath blight pathogen. Sci Rep. 2017;7. 
21. Baiyee B, Pornsuriya C, Ito S ichi, Sunpapao A. Trichoderma spirale T76-1 displays biocontrol activity against leaf spot on lettuce (Lactuca sativa L.) caused by Corynespora cassiicola or Curvularia aeria. Biol Control. 2019;129:195-200.

22. Veenstra A, Rafudeen MS, Murray SL. Trichoderma asperellum isolated from African maize seed directly inhibits Fusarium verticillioides growth in vitro. Eur J Plant Pathol. 2019;153:279-83.

23. Karuppiah V, Sun J, Li T, Vallikkannu M, Chen J. Co-cultivation of Trichoderma asperellum GDFS1009 and Bacillus amyloliquefaciens 1841 Causes Differential Gene Expression and Improvement in the Wheat Growth and Biocontrol Activity. Front Microbiol. 2019;10 MAY.

24. Abbasi PA, Cuppels DA, Lazarovits G. Effect of foliar applications of neem oil and fish emulsion on bacterial spot and yield of tomatoes and peppers. Can J Plant Pathol. 2003;25:41-8.

25. ASKEW DJ, LAING MD. An adapted selective medium for the quantitative isolation of Trichoderma species. Plant Pathol. 1993;42:686-90.

26. Ommati F, Zaker M. In vitro and greenhouse evaluations of Trichoderma isolates for biological control of potato wilt disease (Fusarium solani). Arch Phytopathol Plant Prot. 2012;45:1715-23.

27. Khan S, Bagwan NB, Iqbal MA, Tamboli RR. Mass Multiplication and Shelf life of Liquid Fermented final Product of Trichoderma viride in Different Formulations. India Adv BIORESEARCH. 2011;2:178-82.

28. Ponmurugan P, Baby Ul. Evaluation of fungicides and biocontrol agents against Phomopsis canker of tea under field conditions. Australas Plant Pathol. 2007;36:68-72.

\section{Tables}

Table 1: Bio-efficacy of T. asperellum 2\% AS against dieback disease under field conditions in Darjeeling Zone

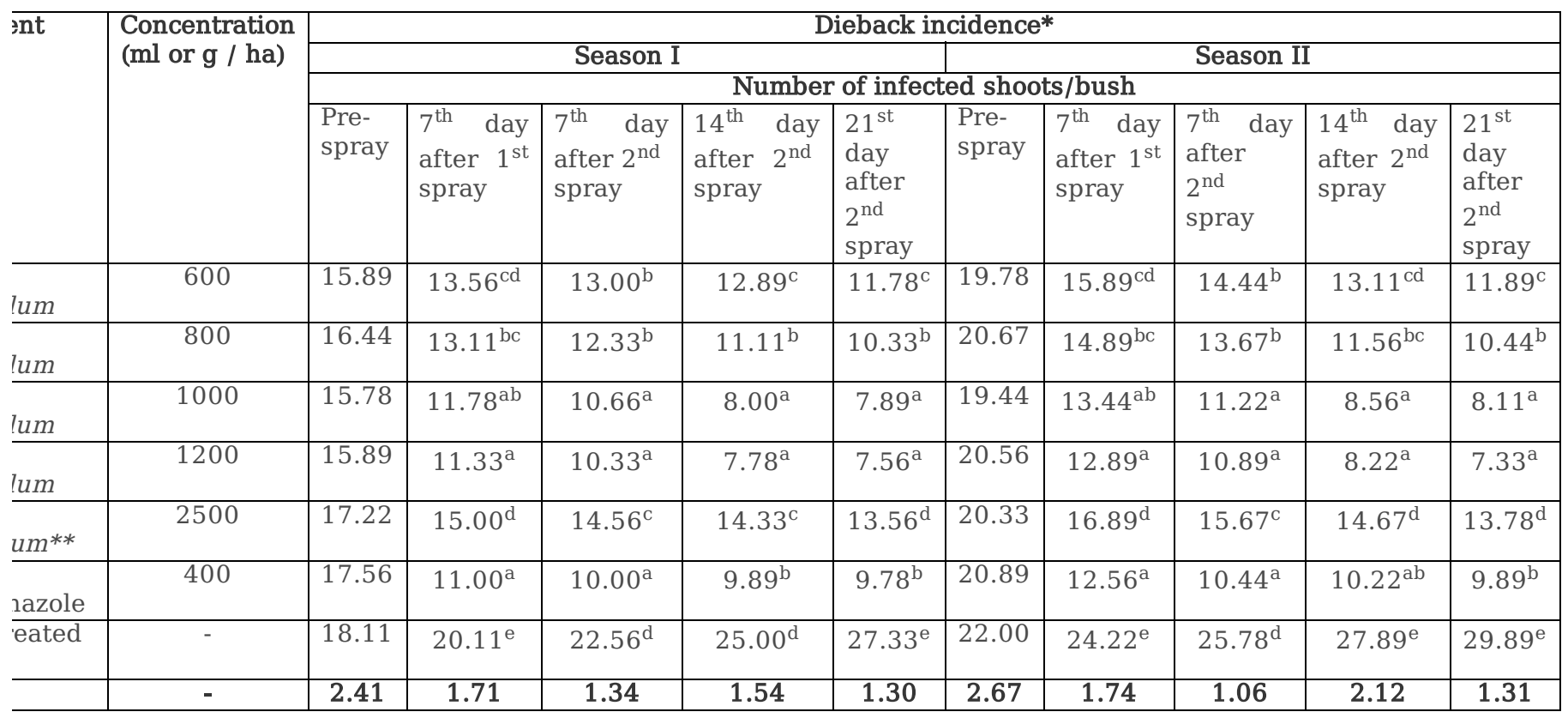

*Mean of three replications

**Market sample

Table 2: Bio-efficacy of T. asperellum 2\% AS against dieback disease under field conditions in Dooars Zone 


\begin{tabular}{|c|c|c|c|c|c|c|c|c|c|c|c|}
\hline \multirow[t]{4}{*}{ ient } & \multirow{4}{*}{$\begin{array}{l}\text { Concentration } \\
(\mathrm{ml} \text { or } \mathrm{g} / \mathrm{ha})\end{array}$} & \multicolumn{10}{|c|}{ Dieback incidence* } \\
\hline & & \multicolumn{5}{|c|}{ Season I } & \multicolumn{5}{|c|}{ Season II } \\
\hline & & \multicolumn{10}{|c|}{ Number of infected shoots/bush } \\
\hline & & $\begin{array}{l}\text { Pre- } \\
\text { spray }\end{array}$ & $\begin{array}{l}7^{\text {th }} \text { day } \\
\text { after } 1^{\text {st }} \\
\text { spray }\end{array}$ & $\begin{array}{l}7^{\text {th }} \text { day } \\
\text { after } 2^{\text {nd }} \\
\text { spray }\end{array}$ & $\begin{array}{l}14^{\text {th }} \text { day } \\
\text { after } 2^{\text {nd }} \\
\text { spray }\end{array}$ & $\begin{array}{l}21^{\text {st }} \\
\text { day } \\
\text { after } \\
2^{\text {nd }} \\
\text { spray }\end{array}$ & $\begin{array}{l}\text { Pre- } \\
\text { spray }\end{array}$ & $\begin{array}{l}7^{\text {th }} \text { day } \\
\text { after } 1^{\text {st }} \\
\text { spray }\end{array}$ & $\begin{array}{l}7^{\text {th }} \text { day } \\
\text { after } \\
2^{\text {nd }} \\
\text { spray }\end{array}$ & $\begin{array}{l}14^{\text {th }} \text { day } \\
\text { after } 2^{\text {nd }} \\
\text { spray }\end{array}$ & $\begin{array}{l}21^{\text {st }} \\
\text { day } \\
\text { after } \\
2^{\text {nd }} \\
\text { spray } \\
\end{array}$ \\
\hline llum & 600 & 21.44 & $15.78^{\mathrm{cd}}$ & $15.11^{\mathrm{c}}$ & $14.22^{\mathrm{C}}$ & $13.11^{\mathrm{d}}$ & 17.78 & $14.11^{\mathrm{C}}$ & $14.00^{\mathrm{C}}$ & $12.33^{\mathrm{c}}$ & $11.67^{\mathrm{C}}$ \\
\hline llum & 800 & 19.89 & $14.89^{\mathrm{bc}}$ & $13.44^{\mathrm{b}}$ & $11.89^{\mathrm{b}}$ & $10.78^{c}$ & 19.11 & $13.44^{\mathrm{bc}}$ & $12.56^{\mathrm{b}}$ & $10.44^{\mathrm{b}}$ & $9.33^{\mathrm{b}}$ \\
\hline llum & 1000 & 20.00 & $14.00^{\mathrm{ab}}$ & $12.56^{\mathrm{a}}$ & $9.89^{\mathrm{a}}$ & $8.56^{\mathrm{a}}$ & 18.44 & $12.45^{\mathrm{ab}}$ & $11.11^{\mathrm{a}}$ & $8.45^{\mathrm{a}}$ & $7.78^{\mathrm{a}}$ \\
\hline Ilum & 1200 & 20.78 & $13.56^{\mathrm{a}}$ & $12.33^{\mathrm{a}}$ & $9.78^{\mathrm{a}}$ & $8.22^{\mathrm{a}}$ & 18.67 & $12.00^{\mathrm{a}}$ & $10.56^{\mathrm{a}}$ & $8.22^{\mathrm{a}}$ & $7.22^{\mathrm{a}}$ \\
\hline num** & 2500 & 20.89 & $16.44^{\mathrm{d}}$ & $15.67^{C}$ & $14.77^{\mathrm{c}}$ & $13.56^{\mathrm{d}}$ & 19.33 & $15.78^{d}$ & $15.67^{d}$ & $14.22^{\mathrm{d}}$ & $13.44^{\mathrm{d}}$ \\
\hline snazole & 400 & 20.67 & $13.11^{\mathrm{a}}$ & $12.00^{\mathrm{a}}$ & $10.78^{\mathrm{ab}}$ & $9.44^{b}$ & 18.89 & $11.67^{\mathrm{a}}$ & $10.22^{\mathrm{a}}$ & $9.00^{\mathrm{ab}}$ & $8.89^{b}$ \\
\hline reated & - & 22.67 & $24.67^{\mathrm{e}}$ & $26.56^{\mathrm{d}}$ & $28.89^{d}$ & $31.33^{\mathrm{e}}$ & 20.78 & $23.11^{\mathrm{e}}$ & $25.56^{\mathrm{e}}$ & $27.56^{\mathrm{e}}$ & $29.89^{\mathrm{e}}$ \\
\hline & - & 2.82 & 0.97 & 0.81 & 1.11 & & 2.39 & 1.30 & 1.40 & 1.59 & 1.01 \\
\hline
\end{tabular}

*Mean of three replications

**Market sample

Table 3: Bio-efficacy of T. asperellum 2\% AS against dieback disease under field conditions in Assam Zone

\begin{tabular}{|c|c|c|c|c|c|c|c|c|c|c|c|}
\hline \multirow[t]{4}{*}{ ient } & \multirow{4}{*}{$\begin{array}{l}\text { Concentration } \\
\text { (ml or g / ha) }\end{array}$} & \multicolumn{10}{|c|}{ Dieback incidence* } \\
\hline & & \multicolumn{5}{|c|}{ Season I } & \multicolumn{5}{|c|}{ Season II } \\
\hline & & \multicolumn{10}{|c|}{ Number of infected shoots/bush } \\
\hline & & $\begin{array}{l}\text { Pre- } \\
\text { spray }\end{array}$ & $\begin{array}{l}7^{\text {th }} \text { day } \\
\text { after } 1^{\text {st }} \\
\text { spray }\end{array}$ & $\begin{array}{l}7^{\text {th }} \text { day } \\
\text { after } 2^{\text {nd }} \\
\text { spray }\end{array}$ & $\begin{array}{l}14^{\text {th }} \text { day } \\
\text { after } 2^{\text {nd }} \\
\text { spray }\end{array}$ & $\begin{array}{l}21^{\text {st }} \\
\text { day } \\
\text { after } \\
2^{\text {nd }} \\
\text { spray }\end{array}$ & $\begin{array}{l}\text { Pre- } \\
\text { spray }\end{array}$ & $\begin{array}{l}7^{\text {th }} \text { day } \\
\text { after } 1^{\text {st }} \\
\text { spray }\end{array}$ & $\begin{array}{l}7^{\text {th }} \text { day } \\
\text { after } \\
2^{\text {nd }} \\
\text { spray }\end{array}$ & $\begin{array}{l}14^{\text {th }} \text { day } \\
\text { after } 2^{\text {nd }} \\
\text { spray }\end{array}$ & $\begin{array}{l}21^{\text {st }} \\
\text { day } \\
\text { after } \\
2^{\text {nd }} \\
\text { spray }\end{array}$ \\
\hline llum & 600 & 21.78 & $16.78^{c}$ & $15.89^{b c}$ & $15.00^{\mathrm{d}}$ & $14.00^{\mathrm{d}}$ & 23.67 & $18.22^{\mathrm{cd}}$ & $17.11^{\mathrm{cd}}$ & $14.67^{\mathrm{C}}$ & $12.33^{d}$ \\
\hline llum & 800 & 22.00 & $16.00^{\mathrm{bc}}$ & $15.11^{b}$ & $13.22^{c}$ & $11.89^{c}$ & 24.44 & $16.89^{\mathrm{bc}}$ & $15.78^{b c}$ & $12.56^{b}$ & $10.78^{C}$ \\
\hline $11 \mathrm{um}$ & 1000 & 20.67 & $14.56^{\mathrm{ab}}$ & $13.33^{a}$ & $9.78^{a}$ & $8.67^{a}$ & 23.00 & $15.33^{\mathrm{ab}}$ & $13.67^{a}$ & $10.33^{a}$ & $8.56^{\mathrm{a}}$ \\
\hline Ilum & 1200 & 21.44 & $14.00^{\mathrm{a}}$ & $13.00^{\mathrm{a}}$ & $9.56^{\mathrm{a}}$ & $8.33^{a}$ & 22.89 & $14.89^{a}$ & $12.89^{a}$ & $9.89^{a}$ & $8.00^{\mathrm{a}}$ \\
\hline num** & 2500 & 21.22 & $17.56^{c}$ & $16.89^{c}$ & $16.33^{\mathrm{e}}$ & $14.67^{d}$ & 24.22 & $19.00^{d}$ & $18.00^{\mathrm{d}}$ & $16.33^{d}$ & $13.56^{d}$ \\
\hline snazole & 400 & 21.89 & $13.78^{a}$ & $12.67^{\mathrm{a}}$ & $11.34^{b}$ & $10.00^{b}$ & 23.78 & $14.22^{\mathrm{a}}$ & $12.78^{a}$ & $11.22^{\mathrm{ab}}$ & $9.67^{b}$ \\
\hline reated & - & 23.33 & $25.33^{d}$ & $26.89^{d}$ & $29.22^{f}$ & $30.44^{\mathrm{e}}$ & 25.67 & $28.33^{\mathrm{e}}$ & $29.89^{e}$ & $31.78^{\mathrm{e}}$ & $33.66^{\mathrm{e}}$ \\
\hline & - & 2.79 & 1.68 & 1.66 & 1.16 & 1.10 & 3.02 & 1.61 & 1.52 & 1.48 & 1.02 \\
\hline
\end{tabular}

*Mean of three replications

**Market sample

Table 4: Effect of T. asperellum 2\%AS on tea yield 


\begin{tabular}{|c|c|c|c|c|c|c|c|c|c|c|c|c|c|}
\hline \multirow[t]{3}{*}{ satment } & \multirow[t]{3}{*}{ Concentration /ha } & \multicolumn{4}{|c|}{ Darjeeling } & \multicolumn{4}{|c|}{ Dooars } & \multicolumn{4}{|c|}{ Assam } \\
\hline & & \multicolumn{2}{|c|}{$\begin{array}{l}\text { Season-1 } \\
(2016)\end{array}$} & \multicolumn{2}{|c|}{$\begin{array}{c}\text { Season-2 } \\
\text { (2018) }\end{array}$} & \multicolumn{2}{|c|}{ Season-1 (2016) } & \multicolumn{2}{|c|}{$\begin{array}{c}\text { Season-2 } \\
(2018)\end{array}$} & \multicolumn{2}{|c|}{$\begin{array}{c}\text { Season-1 } \\
(2017)\end{array}$} & \multicolumn{2}{|c|}{ Season-2 (2018) } \\
\hline & & $\mathrm{A}^{*}$ & $\mathrm{~B}$ & $\mathrm{~A}^{*}$ & $\mathrm{~B}$ & $\mathrm{~A}^{*}$ & $\mathrm{~B}$ & $\mathrm{~A}^{*}$ & $\mathrm{~B}$ & $\mathrm{~A}^{*}$ & $\mathrm{~B}$ & $\mathrm{~A}^{*}$ & $\mathrm{~B}$ \\
\hline $\begin{array}{l}\text {-T. } \\
\text { serellum }\end{array}$ & $600 \mathrm{ml}$ & $2.60^{\mathrm{c}}$ & 403 & $2.43^{\mathrm{c}}$ & 377 & $10.64 \mathrm{~cd}$ & 1652 & $10.68 \mathrm{c}$ & 1658 & $14.39 \mathrm{~d}$ & 2234 & $13.79 \mathrm{~cd}$ & 2141 \\
\hline $\begin{array}{l}-T . \\
\text { serellum }\end{array}$ & $800 \mathrm{ml}$ & $2.63^{b c}$ & 408 & $2.46^{\mathrm{c}}$ & 382 & $10.71 \mathrm{bc}$ & 1663 & $10.89 \mathrm{~b}$ & 1691 & $14.54 \mathrm{c}$ & 2258 & $13.93 \mathrm{bc}$ & 2163 \\
\hline $\begin{array}{l}\text { - T. } \\
\text { serellum }\end{array}$ & $1000 \mathrm{ml}$ & $2.72^{\mathrm{a}}$ & 422 & $2.55^{\mathrm{a}}$ & 395 & 10.91a & 1694 & $11.10 \mathrm{a}$ & 1724 & $14.91 \mathrm{a}$ & 2315 & $14.28 \mathrm{a}$ & 2216 \\
\hline $\begin{array}{l}\text { T. } \\
\text { serellum }\end{array}$ & $1200 \mathrm{ml}$ & $2.74^{\mathrm{a}}$ & 425 & $2.57^{\mathrm{a}}$ & 399 & $10.97 a$ & 1703 & $11.14 \mathrm{a}$ & 1729 & $14.97 \mathrm{a}$ & 2324 & $14.36 a$ & 2229 \\
\hline $\begin{array}{l}T . \\
\text { zzianum** }\end{array}$ & $2500 \mathrm{~g}$ & $2.55^{\mathrm{d}}$ & 396 & $2.39^{d}$ & 371 & $10.55 d$ & 1638 & $10.53 \mathrm{~d}$ & 1635 & $14.25 \mathrm{e}$ & 2212 & $13.72 d$ & 2131 \\
\hline xaconazole & $400 \mathrm{ml}$ & $2.67^{b}$ & 415 & $2.51^{\mathrm{b}}$ & 390 & $10.79 \mathrm{~b}$ & 1675 & $10.98 \mathrm{~b}$ & 1705 & $14.79 \mathrm{~b}$ & 2296 & $14.08 \mathrm{~b}$ & 2185 \\
\hline $\begin{array}{l}\text { Untreated } \\
\text { itrol }\end{array}$ & - & $2.43^{\mathrm{e}}$ & 377 & $2.28^{\mathrm{e}}$ & 354 & $9.78 \mathrm{e}$ & 1519 & $9.94 \mathrm{e}$ & 1543 & $13.34 \mathrm{f}$ & 2071 & $12.77 \mathrm{e}$ & 1983 \\
\hline$\longdiv { 1 }$ & - & 0.04 & - & 0.03 & - & 0.10 & - & 0.09 & & 0.10 & & 0.19 & - \\
\hline
\end{tabular}

*A - Green leaf yield (Kg/Plot) obtained from six plucking (harvestings)

B- Made tea yield (kg/ha/year), ** Market sample

Table 5: Evaluation of phytotoxicity of T. asperellum $2 \%$ AS on tea plants at Darjeeling, Dooars and Assam zone

Treatments

Phytotoxicity observations during $1^{\text {st }}$ and $2^{\text {nd }}$ year

Leaf tip Leaf surface Wilting of leaf Vein clearing Necrosis Epinasty Hyponasty

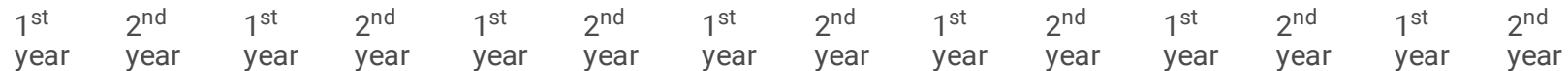

Observations before the treatment spray (day-0)

$\begin{array}{llllllllllllll}\text { T1- Ta } 2 \% \text { AS } 4 & 0 & 0 & 0 & 0 & 0 & 0 & 0 & 0 & 0 & 0 & 0 & 0 & 0\end{array}$

$\mathrm{ml} / \mathrm{L}$

$\begin{array}{llllllllllllll}\text { T2- Ta } 2 \% \text { AS } 8 & 0 & 0 & 0 & 0 & 0 & 0 & 0 & 0 & 0 & 0 & 0 & 0 & 0\end{array}$

$\mathrm{ml} / \mathrm{L}$

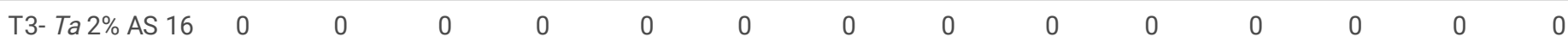

$\mathrm{ml} / \mathrm{L}$

Observations 3 days after treatment spray

$\begin{array}{llllllllllllll}\mathrm{T} 1-\mathrm{Ta} 2 \% \text { AS } 4 & 0 & 0 & 0 & 0 & 0 & 0 & 0 & 0 & 0 & 0 & 0 & 0 & 0\end{array}$

$\mathrm{ml} / \mathrm{L}$

$\begin{array}{lllllllllllllll}\text { T2- Ta } 2 \% \text { AS } 8 & 0 & 0 & 0 & 0 & 0 & 0 & 0 & 0 & 0 & 0 & 0 & 0 & 0 & 0\end{array}$

$\mathrm{ml} / \mathrm{L}$

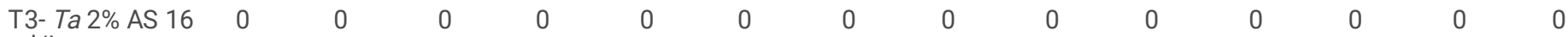

$\mathrm{ml} / \mathrm{L}$

Observations 7 days after treatment spray

$\begin{array}{lllllllllllllll}\mathrm{T} 1-\mathrm{Ta} 2 \% \text { AS } 4 & 0 & 0 & 0 & 0 & 0 & 0 & 0 & 0 & 0 & 0 & 0 & 0 & 0 & 0\end{array}$

$\mathrm{ml} / \mathrm{L}$

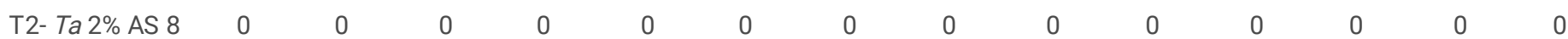

$\mathrm{ml} / \mathrm{L}$

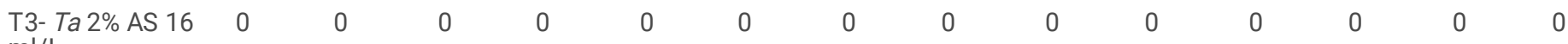

$\mathrm{ml} / \mathrm{L}$

Observations 14 days after treatment spray

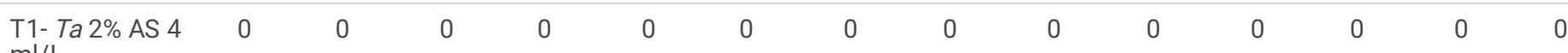

$\mathrm{ml} / \mathrm{L}$

$\begin{array}{lllllllllllllll}\text { T2- Ta } 2 \% \text { AS } 8 & 0 & 0 & 0 & 0 & 0 & 0 & 0 & 0 & 0 & 0 & 0 & 0 & 0 & 0\end{array}$

$\mathrm{ml} / \mathrm{L}$

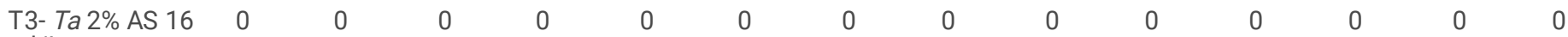

$\mathrm{ml} / \mathrm{L}$ 
Figures

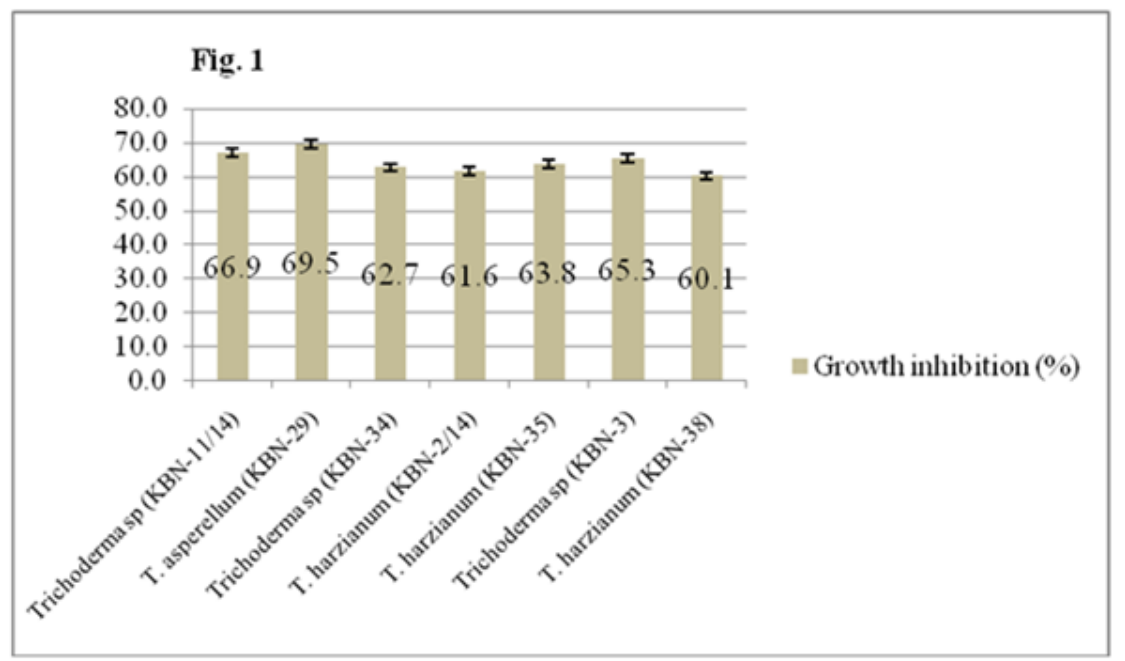

Figure 1

In vitro bioassay of T. asperellum (KBN-29) against F. solani

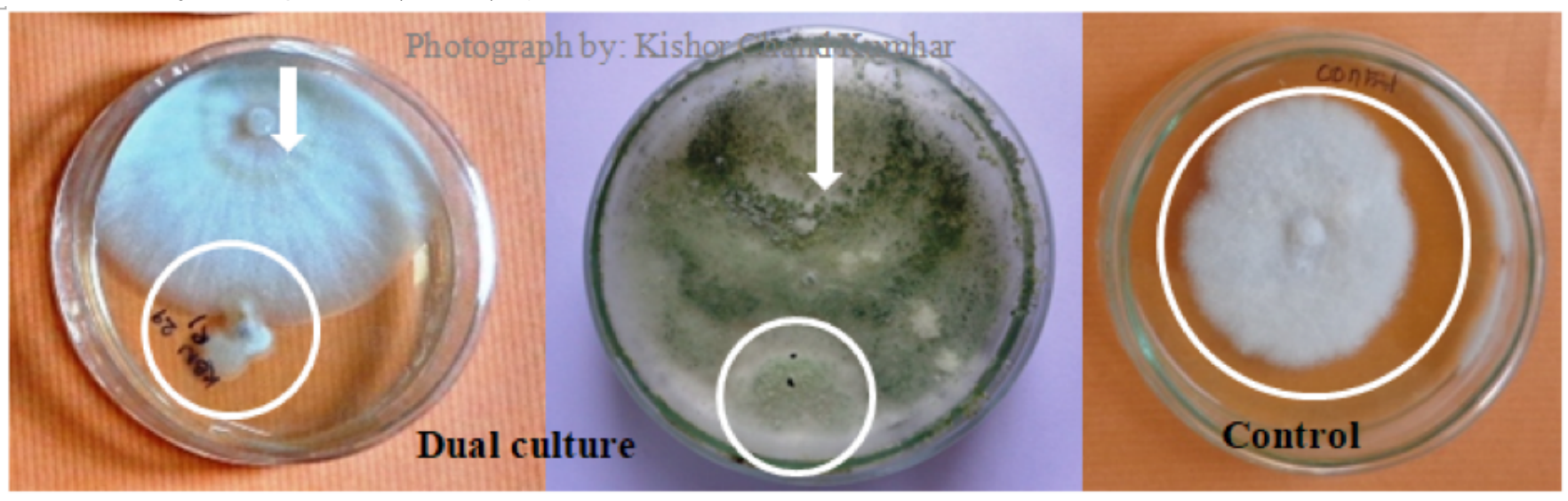

Figure 2

In vitro bioassay of T. asperellum (KBN-29) against F. solani - Pathogen's growth (circle), growth of T. asperellum (arrow)

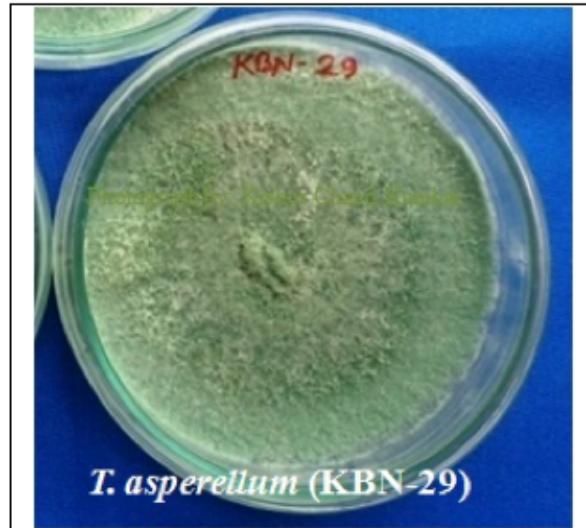

TCACATCAGAAAGTTGGGTGTTTTACGGACGTGGACGCGCCGC GCTCCCGGTGCGAGTTTGCAAACTACTCCAGGAGAGGCTGCGG CGAGACCGCCACTTATTICGGGGCCGGCACCCTGTGAGGGGTCC CGATCCCCAACGCCGATCCCCCGGAGGGGTTCGAGGGTTGAAA TGACGCTCGGACAGGCATGCCCGCCAGAATACTGGCGGGCGCA ATTGCGTTCAAAGATTOGATGATTCACTGAATICTCAATTCACAT TACTTATCGCATCCTCGTICTTCATCGATGCCAGAACCAAGAGAT CCGTIGTTGAAAGTTTTGATTCATTTIGAATTITTGCTCAGAGCTG TAAGAAATACGTCCGCGAGGGGACTACAGAAAGAGTTTGCTTG GTTCCTCGGCGGGCGCCTGGTTCCGGGGCTGCGACGCACCCGG GGCTGACCCCGCCGAGGCAACAGTTTGGTAACGTTCACATTGGT TTGGGAGTTGTAAACTCGGTAATGATCCCTCCGCAGGTTCACCT ACGGAA 
Figure 3

T. asperellum strain (LHS: pure culture and RHS: Nucleotide sequence)

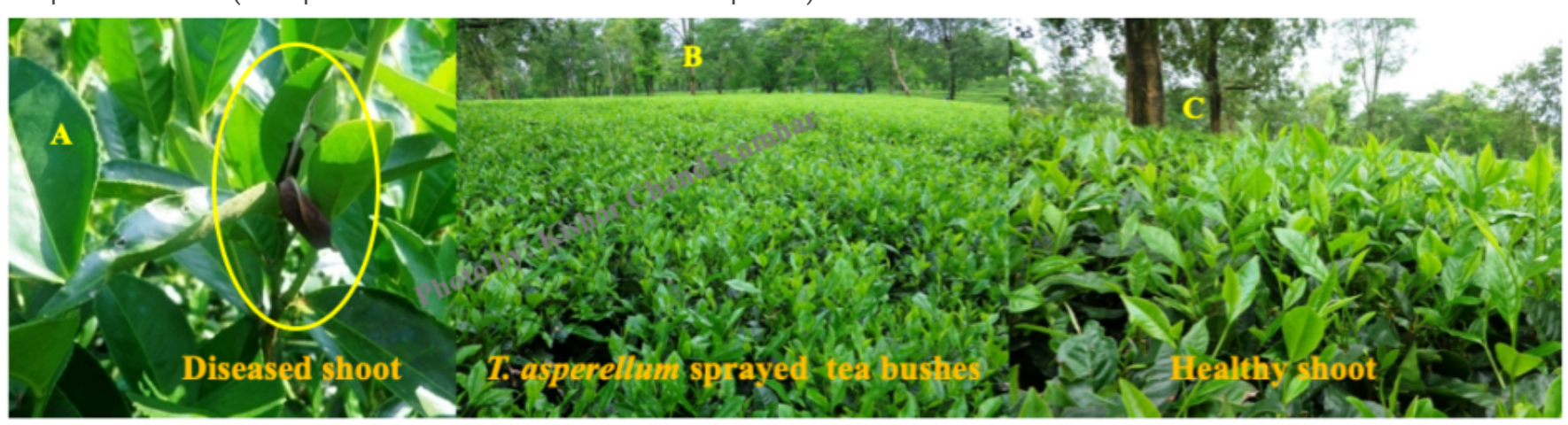

Figure 4

Performance of T. asperellum on tea plantation: A- Diseased shoot, B- Sprayed bushes, C-Post spray emergence of healthy shoots

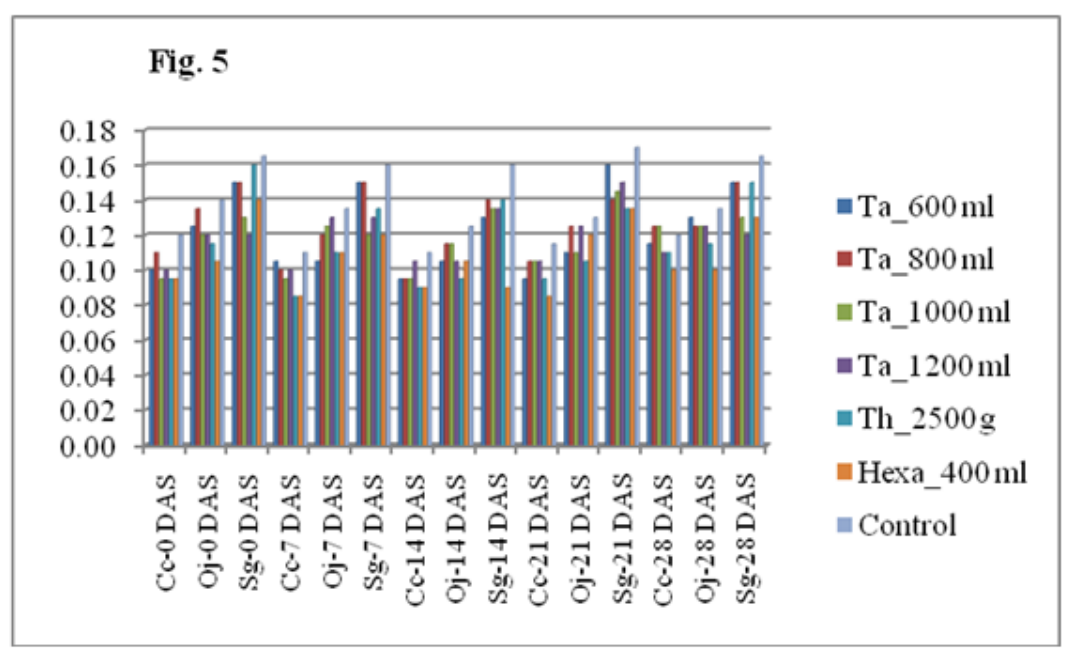

Figure 5

Effect of T. asperellum 2\% AS on beneficial insects of tea in Darjeeling (Average of 2 years)

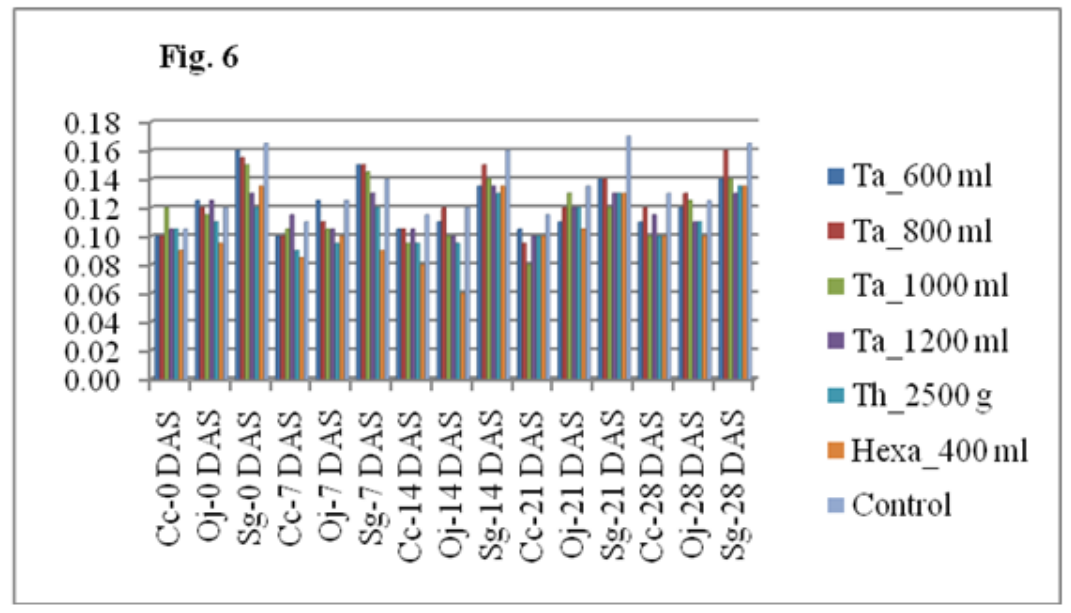

\section{Figure 6}

Effect of T. asperellum 2\% AS on beneficial insects of tea in Dooars (Average of 2 years) 


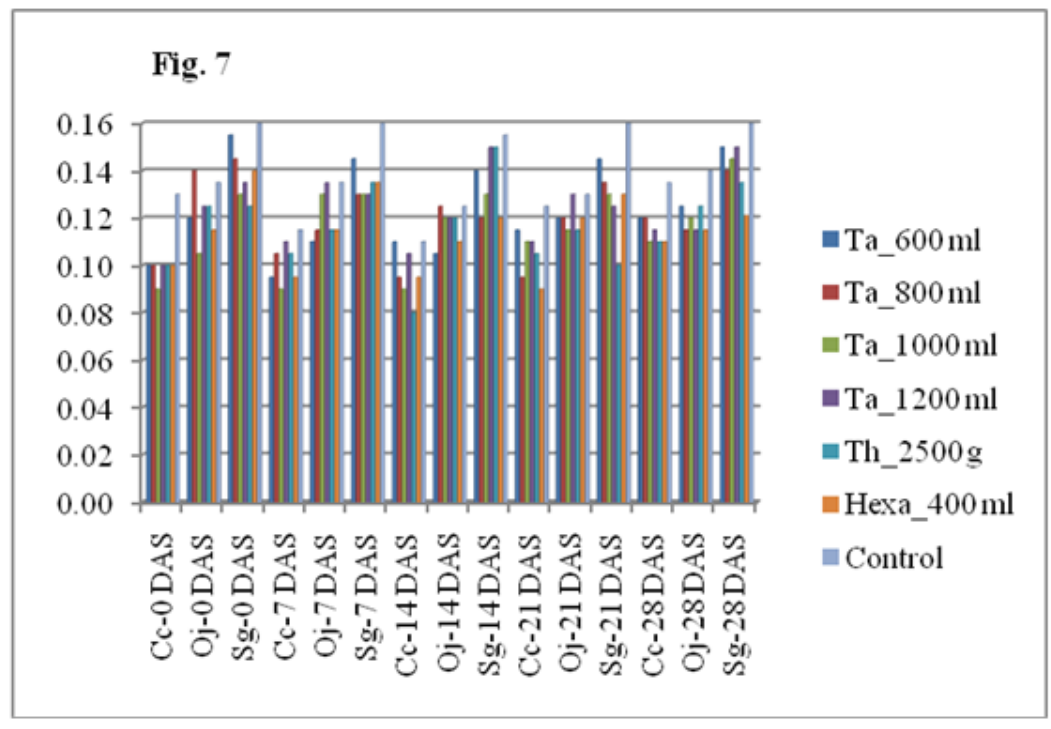

Figure 7

Effect of T. asperellum 2\% AS on beneficial insects of tea in Assam (Average of 2 years) 